\title{
Financial Analysis to Predict Financial Distress of Small and Medium-Sized Entities in Malang City
}

\author{
Kartika DS Susilowati*, Nur Indah Riwajanti, Retno Widiastuti \\ Accounting Department \\ State Polytechnic of Malang \\ Malang, Indonesia \\ * kartika.dewi@polinema.ac.id
}

\begin{abstract}
The goal of this study is to examine financial ratios to predict financial distress in small and medium-sized enterprises (SMEs) in the city of Malang. The financial ratios used as vector predictors are Liquidity Ratio proxied by Current Ratio (CR), Leverage Ratio proxied by Debt to Asset Ratio (DAR) and Profitability Ratio proxied by Return on Asset (ROA). Based on the results of multiple regression analysis with a significance level of $5 \%$, the results of the study concluded that the model is fit and can be used to predict financial distress of SMEs in Malang city. Result of the study shows that: (1) profitability has a negative and significant effect in predicting financial distress of SMEs in Malang city with a wald test value is positive amounted to 7.167 and 0.007 significance value $<0.05$, (2) liquidity has no effect in predicting financial distress with a wald test value is positive amounted to 2.374 and 0.123 significance value $>0.05$, (3) leverage has a positive and significant effect in predicting financial distress of SMEs in Malang city with a wald test value is positive amounted to 17.995 and 0.000 significance value $<0.05$. On the basis of the above findings, it is suggested that: (1) for small and medium-sized companies, it may be used as a consideration for taking corrective action before it evolves into serious financial distress and leads to bankruptcy; (2) for academics and researchers, knowledge of the effect of profitability, liquidity and leverage in predicting financial distress, which may increase empirical and scientific evidence, may be used as a basis for predicting financial distress, (3) For the investor, it can be used as a consideration in making the right investment decisions.
\end{abstract}

\section{Keywords—profitability, liquidity, leverage, financial distress}

\section{INTRODUCTION}

Small and medium-sized entities (SMEs) play a critical role in global economic development. They contribute significantly to economic development through job creation [1-3], poverty reduction [4], and bringing new invention and creativity [5,6]. As also suggested by Yosina and Taghizadeh-Hesary [7] that the role of Small and Medium Enterprises (SMEs) in Asian economy can be seen from: (1) its position as a major player in economic activity in various sectors, (2) the largest provider of employment, (3) an important player in the development of local economy activities and community empowerment, (4) creators of new markets and sources of innovation, and (5) their contribution to maintain the balance of payments through export activities.

However, considering the strong contribution of small and medium-sized businesses to the national economy, it turns out that this sector still has a myriad of very basic problems. These small and medium-sized businesses are still poor in business management skills, human resource productivity (HR) is still limited, and access to capital and market penetration is poor [8], low human resource quality and low creativity [9], development inefficiency [10] and so on. The problems confirms previous research by ADB [11] which states that a large number of small and medium-sized enterprises (SMEs) have not been bankable, either due to lack of clear financial management or lack of managerial and financial capability.

If SMEs have a long-term financial difficulty and are unable to change their business operations, they will face difficulties in meeting a very tight level of competition such that they will suffer losses which, in turn, will lead to bankruptcy (financial distress). According to Platt and Platt [12], financial distress is a phase of deterioration in financial conditions that arises prior to bankruptcy or liquidation. If this is not fixed quickly, it will have a huge effect on businesses, such as the lack of confidence from stakeholders, and then the corporation will go bankrupt.

According to Luciana [13], a business is categorized as suffering from financial distress if the business experiences a negative operating profit for two consecutive years. A corporation that has had a negative operating result for more than a year suggests that the financial position of an organization has deteriorated. If no corrective action has been taken by the management of the company, the company could go bankrupt. Companies suffering financial difficulties typically have a low profitability ratio. Meanwhile, the liquidity ratio of firms facing financial difficulty is usually below 1 , which means that the existing assets of the company are insufficient to support the total liability of the firm. The equity ratio of firms suffering financial difficulty is typically higher than 1 , which means that the liability of the company is greater than the overall assets of the firm.

According to Luciana [14], the forecast of the financial potential of the firm is usually carried out by external parties of 
the firm, such as: customers, suppliers, auditors, government and company members. External parties typically respond to distress signals such as: distribution delays, diminished product quality, lack of confidence from consumers, unpaid bills from banks or creditors, and so on. To figure out whether or not a company is in trouble, the review of financial statements by calculating financial ratios may be one of the methods for predicting financial problems faced by the company. This financial ratios are metrics that are used to forecast financial distress. Altman [15] points out that general ratios such as profitability, liquidity, leverage and cash flow utilization should be used as the most relevant metrics for forecasting financial problems and bankruptcies.

According to Mamduh [16], the profitability ratio is a ratio that calculates the capacity of the company to achieve net profits at a given level of sales, assets and share capital. The ratio is expressed in the Return On Assets (ROA). Wahyu [17] claims that profitability illustrates the reliability and efficacy of using business properties to achieve profits. With sufficient capital, the organization is less likely to face financial distress in the future. In addition to the profitability ratios, the liquidity ratios can also be used to forecast financial distress. According to Hendra [18], the liquidity ratio is a ratio that measures the ability of a business to satisfy its short-term obligations that are due. Current Ratio (CR) is the liquidity ratio widely used in various studies. If the company is able to manage and manage off its short-term commitments adequately, the risk of the company to suffer financial difficulties would be minimized. In addition to the liquidity ratio, the debt ratio can also be used as a measure for forecasting financial distress. According to Keown [19], the debt-to-leverage ratio indicates how much debt a corporation requires to finance its investments. The debt to total asset ratio is the leverage ratio that is widely used. With this ratio, creditors will calculate how high the risk of debt owed to a business is.

The goal of this study is to examine financial ratios to predict financial distress in small and medium-sized enterprises (SMEs) in the city of Malang. As variable predictors of financial distress, this study use liquidity ratio proxied by Current Ratio (CR), leverage ratio proxied by Debt to Asset Ratio (DAR) and profitability Ratio proxied by Return on Asset (ROA). The rest of the article is organized as follows: Section 2 reviews the literature on financial ratio used to predict financial distress of SMES in Malang city and the conceptual framework. Section 3 provides the research methodology and develops testable hypotheses. Section 4 shows the regression results. Finally, the article closes with a conclusion and suggests implications to SMEs, future research and investors.

\section{LITERATURE REVIEW AND HYPOTHESIS}

\section{A. Financial Distress}

According to Mamduh [16], financial distress can be represented from two extremes, namely short-term to insolvent liquidity difficulties. Short-term financial problems are typically short-term, but they may grow into substantial ones. Financial distress indicators can be shown from cash flow analysis, business policy analysis, and company financial reporting. According to Wruck in Sari [20], financial distress is a decline in profitability (benefit) while Elloumi and Gueyie in Sari [20] categorize businesses with financial distress if they encounter negative operating results for two consecutive years. A somewhat different view was articulated by Platt in Luciana [14] that financial distress is a period of deterioration in financial circumstances that exists prior to bankruptcy or liquidation. According to Plat in Luciana [14], the conditions for businesses suffering financial distress are: (1) multiple years of negative recurring net income; (2) an end to dividend payments; and (3) a substantial turnaround or termination of business. Conditions such as the latter are synonymous with a business that is suffering financial distress. In the end, if the company is unable to resolve the following conditions, the company will go bankrupt.

\section{B. Financial Ratios to Predict Financial Distress}

The definition of the financial ratios according to Van Horne in Kasmir [21] is an index that blends two accounting numbers and is derived by dividing one number by another. Financial ratios are used to measure the financial situation and efficiency of the company. The health of the company can be seen through the performance of these financial ratios.

1) Profitability: According to Hendra [18], profitability is a ratio that measures how much effectiveness of company management or executives in creating profits. According to Keown [19], an indicator that can be used as a measure of company profitability is ROA (Return On Asset) which is the return on assets used to generate the company's net income. According to Keown [19] ROA can be calculated by the following formula:

\section{Return on Asset $=\frac{\text { Earnings After Tax }}{\text { Total Asset }}$}

2) Liquidity: According to Lukman [22], liquidity is an indicator of the ability of a business to repay all short-term debt obligations at maturity with existing current assets. According to John [23], the lack of capacity of a company to fulfill its current obligations is a serious liquidity problem, which can lead to forced disposal of assets and other resources and also contribute to solvency and bankruptcy problems. If the company is in a position to adequately manage and pay off its short-term commitments, the risk for the company to suffer financial difficulties would be minimized. There is no definite stipulation as to whether the existing ratio standard is deemed to be good or which must be retained by an organization so it generally depends on the form of business the company operates [22]. However, the current ratio of 2 is considered to be fine. According to Wild [23], this ratio is determined by using the following formula: 


\section{Current Asset Ratio $=\frac{\text { Current Asset }}{\text { Current Liability }}$}

3) Leverage: According to Kasmir [21], the leverage ratio is the ratio used to calculate the degree to which the assets of the company are funded by debt. According to Toto, the higher the volume of debt, the higher the risk for a corporation to encounter financial problems and bankruptcies. According to Lenox et al in Pasaribu [24], bankruptcy typically occurs at a period of default, and the greater the volume of debt, the higher the risk of financial distress. If a company uses more debts for its business, the potential for experiencing financial difficulties in the future will be even greater. If this issue can not be managed properly, the possibility for financial distress is much higher. One of the measures used to calculate leverage is the debt to asset ratio (DAR). According to Hendra [18], this ratio can be calculated using the following formula:

$$
\text { Debt to Asset Ratio }=\frac{\text { Total Debt }}{\text { Total Asset }}
$$

\section{Conceptual Framework}

Financial distress is a period of deterioration in the financial state of the company, and if it is left to carry on, it will lead the company to go bankrupt. Financial instability starts as a business suffers persistent operating losses that cause capital deficiency. To predict the financial distress of a business, an analysis of the financial ratio of the company may be carried out. In general, the measures of profitability, liquidity and debt can be used as significant indicators to assess financial distress.

The profitability ratio measures the capacity of the company to achieve net profits at a specified level of sales, assets and equity capital. The more the company loses, the more likely it is to experience financial distress. This indicates that the lower the profitability of the firm, the higher the likelihood for the firm to suffer financial distress. The liquidity ratio is a measure of the willingness of the company to repay all short-term financial obligations at maturity with available current assets. If the company is in a position to adequately manage and pay off its short-term obligations, the risk for the company to suffer financial distress would be minimized. Meanwhile, the leverage ratio is the factor used to calculate the degree to which the finances of the company are funded by debt. If a company uses more debts for its business, the potential for experiencing financial difficulties in the future will be even greater. If this issue can not be handled properly, the possibility for financial distress is much higher. On the basis of the above description, the conceptual framework can be described as follows:

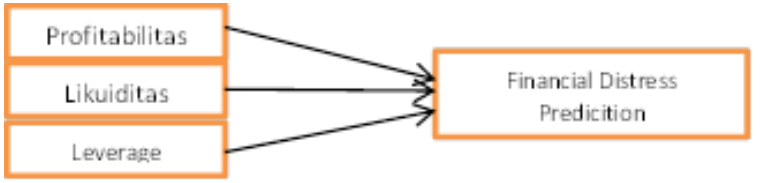

Fig. 1. Conceptual Framework.

\section{Hypothesis}

Hypotheses of the study are as follows:

H1: The greater the profitability of the company, the smaller the probability of the company experiencing financial distress.

$\mathrm{H} 2$ : The greater the liquidity of the company, the smaller the probability of the company experiencing financial distress.

H3: The greater the leverage of the company, the greater the probability the company experiences financial distress.

\section{RESEARCH METHODS}

\section{A. Types of Research}

This study is known as causative (causative) research, i.e. study utilizing the features of a causal relationship between two or more variables. The purpose of this analysis is to investigate the relationship between the independent variable $(\mathrm{X})$ and the dependent variable $(\mathrm{Y})$. The purpose of this study is to explain the impact of Profitability (X1), Liquidity (X2) and Leverage (X3) as independent variables in predicting financial distress (Y) on MSMEs in Malang city as a dependent variable.

\section{B. Population and Samples}

Population is the whole object that follows certain criteria and is connected to the issue under analysis. The community to be observed in this analysis is all small and medium-sized enterprises in Malang, with a community of 112 thousand UMKM, dominated by micro-enterprises engaged in culinary, fashion and digital start-ups. The sample was chosen on the basis of the completeness of the financial data kept by MSMEs during the observation year, namely 2017-2018. In this study, 53 SMEs were selected as the samples.

\section{Forms of Data and Data Sources}

The type of data used in this analysis is secondary data collected from SMEs representatives of the Malang Chamber of Commerce and Industry (KADIN), in the form of financial report notes, mass media publications or other sources related to the research objectives.

\section{Research Variables}

1) Dependent Variable ( $Y$ ): The dependent variable is a variable on which the presence component is affected by the independent variable. In this study, the dependent variable is Financial distress. In this study, a corporation is said to have undergone financial distress if it has reported negative net operating profits for two consecutive years, whereas a 
corporation that has not experienced negative operating profit for two consecutive years is not listed as experiencing financial distress. The year of financial distress suffered by the company shall be the year in the variable period $\mathrm{X}$ and the year following the variable period $\mathrm{X}$. This variable uses a dummy variable for the measurement:

1 (one) $=$ Financial Distress

$0($ zero $)=$ Non Financial Distress

\section{2) Independent Variable $(X)$}

a) Profitability (X1): Profitability is measured using the Return on Assets, which was calculated using the following formula:

$$
\text { Return on Asset }=\frac{\text { Earnings After Tax }}{\text { Total Asset }}
$$

b) Liquidity (X2): Liquidity is measured using the Current Ratio, which was calculated using the following formula:

$$
\text { Current Asset Ratio }=\frac{\text { Current Asset }}{\text { Current Liability }}
$$

c) Leverage (X3): Leverage is measured using the Debt to Asset Ratio, which was calculated using the following formula:

\section{E. Data Analysis Technique}

1) Logistic Regression Analysis Model: The purpose of this analysis is to establish the role of each independent variable in affecting the dependent variable. Logistic regression analysis is used to estimate the effect of the dependent variable on-independent variable. The model of analysis is as follows:

$$
\operatorname{Ln} \frac{\mathrm{P}}{(1-\mathrm{P})}=a 0+b 1 P R O F+b 2 L I Q U I D+b 3 L E V+\in i
$$

Notes:

$$
\begin{aligned}
& \operatorname{Ln} \frac{\mathbb{P}}{\mathbb{P}=\mathbb{P}_{\mathbb{P}}}=\log \text { from the comparison between financial distress } \\
& \text { opportunities and non financial distress } \\
& \text { opportunities } \\
& \text { a }=\text { constant } \\
& \mathrm{b}_{1} \quad=\text { Coefficient regression of profitability } \\
& \mathrm{b}_{2} \quad=\text { Coefficient regression of liquidity } \\
& \mathrm{b}_{3} \quad=\text { Coefficient regression of leverage } \\
& \boldsymbol{\varepsilon}=\text { Error }
\end{aligned}
$$

\section{2) Steps of Analysis}

a) Assessing the validity of the regression model: the precision of the test value determined by the Chi-Square value at the bottom of the Hosmer and Lemeshow test should show a probability value $>0.05$, which means that there is no substantial discrepancy between the expected classification and the observed classification. This means that the logistic regression model is appropriate for further study.

b) Assessing the total model (overall model fit): from-2 $\log$ numbers where at start (Block number $=0$ )-2 $\log$ likelihood numbers must decrease at block number $=1$. A drop in likelihood of logistic regression indicates a better regression model.

\section{F. Hypothesis Testing}

This test aims to partially test the effect of the independent variables on the dependent variable by assuming the other variables are constant. This is obtained by the formula:

Notes:

$\beta \mathrm{n} \quad$ : The regression coefficient of each variable

$\mathrm{S} \beta \mathrm{n} \quad$ : Standard error of each variable

The results of testing the t-statistic with a significance standard of $\alpha=5 \%$ are:

- If sig. $<\alpha$, then Ho is rejected and Ha is accepted. This means that there is a partial influence between the independent variables on the dependent variable.

- If sig. $\geq \alpha$, then Ho is accepted and Ha is accepted. This means that there is no effect partially between the independent variables and the dependent variable.

\section{FINDINGS AND DISCUSSION}

\section{A. Definition of Statistics}

The sample of this analysis was 53 SMES with a period of 2017-2018 years of testing. In 2017 there were 6 companies suffering financial distress and in 2018 there were 7 companies suffering financial distress. Meanwhile, the average profitability of SMEs was 2.19 per cent in 2017 and-4.6 per cent in 2018. Meanwhile, the total liquidity of the SMEs was 1.34 in 2017 and 1.39 in 2018 . It can also be inferred that the liquidity of the SMEs can be said to be very strong since it is above 1. The SMEs leverage was 0.64 in 2017 and 0.65 in 2018. A leverage of more than 60 per cent can be said to be very dangerous, if the company is not able to make profit adequately from the debt it has, the company can go bankrupt.

\section{B. Logistic Regression Analysis Test Results}

1) Test of Regression Model Viability: Based on the hosmer and lemeshow test in Table 1, the value of Chi Square is 1,182 with a sig value of 0,997 . It can be shown from these data that the Sig value is higher than the alpha value (0.05), which means that there is no substantial difference between the expected classification and the observed classification. This means that the logistic regression model can be used for 
further research. Chi-square calculations are intended to assess the effect of profitability, liquidity and leverage in predicting financial distress.

TABLE I. HOSMER AND LEMESHOW TEST

\begin{tabular}{|l|l|l|l|}
\hline Step & \multicolumn{1}{c|}{ Chi-square } & df & Sig. \\
\hline 1 & 1.182 & 8 & .997 \\
\hline
\end{tabular}

2) Overall Model Fit Test: To find out whether the independent variables added to the model can significantly improve the model, the $-2 \operatorname{LogL}$ statistic is used. In Block Number $=0$ (Beginning Block), the first model with only constants without any independent variables, the value of -2 Log Likelihood is 170.030. Based on table 2 and table 3, it can be seen that Block Number 0 is 170,030 and Block Number 1 decreases to 88,801 , so it can be concluded that this regression model is feasible to use.

TABLE II. BLOCK 0: BeGINNING BLOCK ITERATION HISTORY ${ }^{\mathrm{A}, \mathrm{B}, \mathrm{C}}$

\begin{tabular}{|ll|l|l|}
\hline \multirow{2}{*}{ Iteration } & \multicolumn{1}{c|}{$\begin{array}{c}\text {-2 Log } \\
\text { likelihood }\end{array}$} & \multicolumn{1}{c|}{ Coefficients } \\
\cline { 3 - 4 } & & 171.827 & Constant \\
\hline Step & 1 & 170.039 & -1.304 \\
0 & 2 & 170.030 & -1.540 \\
& 3 & 170.030 & -1.558 \\
\hline
\end{tabular}

a. Constant is included in the model.

b. Initial -2 Log Likelihood: 170.030

c. Estimation terminated at iteration number 4 because parameter estimates changed by less than .001

TABLE III. BLOCK $1:$ METHOD $=$ ENTER

ITERATION HISTORY ${ }^{\mathrm{A}, \mathrm{B}, \mathrm{C}, \mathrm{D}}$

\begin{tabular}{|l|l|l|l|l|l|}
\hline Iteration & \multirow{2}{*}{$\begin{array}{c}\text { 2 Log } \\
\text { likelihood }\end{array}$} & \multicolumn{4}{|c|}{ Coefficients } \\
\cline { 3 - 6 } & Constant & Profitability & Liquidity & Leverage \\
\hline Step1 & 118.809 & -2.549 & -.024 & -.098 & 2.043 \\
2 & 97.004 & -3.691 & -.043 & -.374 & 3.485 \\
3 & 89.932 & -4.614 & -.065 & -.672 & 4.861 \\
4 & 88.835 & -5.229 & -.079 & -.812 & 5.697 \\
5 & 88.801 & -5.380 & -.081 & -.834 & 5.883 \\
6 & 88.801 & -5.387 & -.082 & -.835 & 5.891 \\
7 & 88.801 & -5.387 & -.082 & -.835 & 5.891 \\
\hline
\end{tabular}

a. Method: Enter

b. Constant is included in the model.

c. Initial -2 Log Likelihood: 170.030

d. Estimation terminated at iteration number 7 because parameter estimates changed by less than .001 .

3) Logistic Regression Analysis Test: To test the hypothesis, a logistic regression test was used which was carried out on all variables, namely profitability, liquidity and leverage in predicting financial distress. Based on table 4 the test results are as follows:
TABLE IV. LOGISTIC REgRESSION ANALYSIS TEST RESUlTS VARIABLES IN THE EQUATION

\begin{tabular}{|l|l|l|l|l|l|l|}
\hline & \multicolumn{1}{|c|}{ B } & \multicolumn{1}{|c|}{ S.E. } & \multicolumn{1}{|c|}{ Wald } & df & \multicolumn{1}{c|}{ Sig. } & \multicolumn{1}{|c|}{$\operatorname{Exp(B)}$} \\
\hline $\begin{array}{l}\text { Satep Prof } \\
\text { itability }\end{array}$ & -.082 & .030 & 7.167 & 1 & .007 & .922 \\
1 Liquidity & & & & & & \\
Leverage & -.835 & .542 & 2.374 & 1 & .123 & .434 \\
Constant & 5.891 & 1.389 & 17.995 & 1 & .000 & 361.631 \\
\hline
\end{tabular}

a. Variable(s) entered on step 1: Preferabilities, Liquidities, Leverage. $\mathrm{Y}=-5.387+(-0.082) \mathrm{X} 1+(-0.835) \mathrm{X} 2+5.891 \mathrm{X} 3$

The figures generated from these tests can be explained as follows:

a) Constant (a): From the results of the logistic regression analysis, it can be seen that a constant of $-5,387$ shows that without the influence of the independent variables, namely profitability, liquidity and leverage, the probability of financial distress will decrease by 5,387.

b) Regression coefficient (b) X1: The profitability variable $(\mathrm{X} 1)$ has a regression coefficient of -0.082 , meaning that if the profitability variable increases by one unit, the probability of financial distress (Y) will decrease by 0.082 , assuming that the other variables are constant.

c) Regression coefficient (b) X2: The liquidity variable (X2) has a regression coefficient of -0.835 , meaning that if the liquidity variable increases by one unit, the probability of financial distress $(\mathrm{Y})$ will decrease by 0.835 , assuming that the other variables are constant.

d) Regression Coefficient (b) X3: The leverage variable (X3) has a regression coefficient of 5,981, meaning that if the leverage variable increases by one unit, the probability of financial distress (Y) will increase by 5,981, assuming that the other variables are constant.

4) Qualification Matrix: The qualification matrix will illustrate the statistical ability of the regression model to estimate the probability of a business suffering financial distress. Based on Table 5, it can be shown that, according to the forecasts, there are 32 companies in financial distress, although the real findings indicate that there are 18 companies in financial distress. The accuracy of this model is $18 / 32$ or $56.3 \%$. And according to the predictions of companies that do not experience financial distress, there are 48 companies, although the real findings indicate that there are 46 companies that do not experience financial distress. The accuracy of this formula is then $46 / 48$ or $95.8 \%$. 
TABLE V. QUALIFICATION MATRIKS

ClassificAtion TABLE ${ }^{A}$

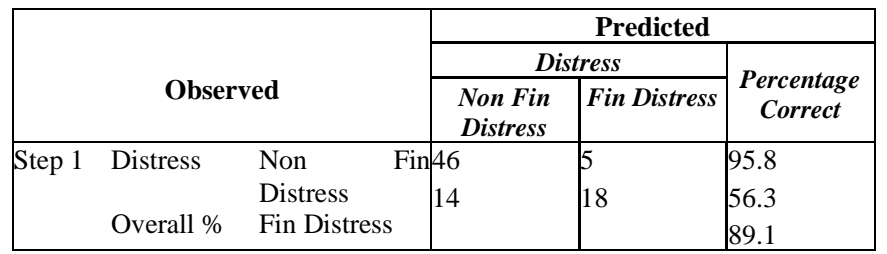

5) Coefficient of Determination Test: Table 6 indicates the Nagelkarke R Square value of 0.592 , which means that the uncertainty of the dependent variable that can be described by an independent variable is $59.2 \%$, while the remaining $40.8 \%$ is described by the uncertainty of other variables outside the test model. Or, combined, the variables of profitability, liquidity and leverage can explain the $59.2 \%$ prediction of financial distress.

TABLE VI. DETERMINATION COEEFICIENT MODEL SUMMARY

\begin{tabular}{|c|l|c|c|}
\hline Step & \multicolumn{1}{|c|}{$\begin{array}{c}\text {-2 Log } \\
\text { likelihood }\end{array}$} & $\begin{array}{c}\text { Cox \& Snell R } \\
\text { Square }\end{array}$ & $\begin{array}{c}\text { Nagelkerke R } \\
\text { Square }\end{array}$ \\
\hline 1 & $88.801^{\mathrm{a}}$ & .357 & .592 \\
\hline
\end{tabular}

a. Estimation terminated at iteration number 7 because parameter estimates changed by less than 001 .

\section{Hypothesis Test}

1) Hypothesis 1 (The higher the profitability, the lower the risk of a company suffering financial distress): Profitability has a major effect on forecasting financial instability when profitability is $0.007<0.05$. The Wald test value indicates the number 7,167 which is greater than the X2 df 1 chart, which is 3,841. As a result, it means that $\mathrm{Ho}$ is refused and $\mathrm{Ha}$ is approved, which means that profitability has a major impact in forecasting financial distress.

2) Hypothesis 2 (The higher the liquidity, the smaller the probability of the company experiencing financial distress): Liquidity has a significant influence in predicting financial distress. The Wald test value shows the number 2,374 which is smaller than the $\mathrm{X} 2$ table df 1 , which is 3,841 . and a significance of $0.123>0.05$. From this result, it means that Ho is accepted and $\mathrm{Ha}$ is rejected, meaning that liquidity does not have a significant effect in predicting financial distress.

3) Hypothesis 3 (The higher the leverage, the greater the probability of the company experiencing financial distress): Leverage has a significant influence in predicting financial distress, because leverage has a significance of $0.000>0.05$. The Wald test value shows the number 17,995 which is greater than the X2 table df 1 , which is 3,841 . From this result, it means that $\mathrm{Ho}$ is rejected and $\mathrm{Ha}$ is accepted, meaning that leverage has a significant effect in predicting financial distress.

\section{DISCUSSION}

The discussion in this section is aimed at explaining the results of the research in accordance with the research objectives as described in the following points:

\section{A. Profitability}

Through logistic regression, it is known that profitability has a significant influence in predicting financial distress. The results of these tests indicate that profitability has a significant and negative influence in predicting financial distress with a significance value of $0.007<\alpha 0.05$ and a Wald test value of 7,167 which is greater than the $\mathrm{X} 2$ table df 1 , which is 3,841 . The findings of this study are consistent with Luciana's research in 2006 as well as Mahde Salehi's research in 2009 which stated that profitability can be used to predict financial distress. Financially distressed SMEs typically have negative profitability. Profitability demonstrates the quality and efficacy of the use of assets to produce income for the business. The negative profitability of the firm implies the ineffectiveness of using the assets of the company to produce net profits, such that if the profitability of the firm begins to fall and is even unfavorable, the risk for the company to go bankrupt would be even higher.

\section{B. Liquidity}

Logistic regression shows that liquidity would not have a major effect on forecasting financial distress. The findings of these analyses demonstrate that liquidity does not have a substantial and negative effect in forecasting financial distress with a value of 2.374, which is lower than X2 table df 1, which is 3.841 and a value of $0.123>0.05$. It can also be inferred that liquidity would not have a major and negative impact on the forecasting of financial distress. The findings of this analysis are consistent with Wahyu's 2009 report, which indicates that liquidity does not have a substantial impact on forecasting financial distress.

Liquidity would not have a significant effect on assessing financial distress and there is no significant difference between the liquidity of financial distressed firms and non-financial distressed firms. The availability of a liquidity ratio deemed to be good is within the range of 2, implying that for every 1 existing obligation the company has 2 current assets are available to offset it. This will further ensure that the company will be able to pay off its current obligations, which are due on time, in order to minimize the risk for financial distress.

\section{Leverage}

Through logistic regression, it is known that leverage has a significant influence in predicting financial distress. The results of these tests indicate that leverage has a significant and positive influence in predicting financial distress with a significance value of $0.000>\alpha 0.05$ and a Wald test value of 17,995 which is greater than the $\mathrm{X} 2$ table df 1 , which is 3,841 . The fidings of this study are consistent with the results of Luciana's research [25], Pasaribu's [24] and Mahde's [26] 
research, which stated that leverage can be used to predict financial distress. Firms who undergo financial distress usually have a net liability that is about as high as their total assets, and there are also firms that have more liability than their actual assets. The percentage of the debt that is more than the net assets leads the overall value of the company 's equity to be negative.

\section{CONCLUSIONS AND RECOMMENDATIONS}

This study was performed to determine the variables that could predict financial distress in SMEs in the city of Malang. The findings of this research are not that far from the results of previous studies. The findings of this study show that the profitability of Return on Assets (ROA) has a negative and significant impact in predicting financial distress on SMEs in Malang, and vice versa, the leverage of the Debt to Asset Ratio (DAR) has a positive and significant effect. In predicting financial distress. In the meantime, the liquidity given by Current Asset Ratia (CR) has little effect on the forecasting of financial distress for SMEs in Malang.

Due to the restricted financial data collected from the SMEs, this analysis has several limitations, namely that the forecast duration of this study only uses financial data for two years, such that the forecast model research is still not able to completely describe the good financial ratios that derive from the financial statement, balance sheet and cash flow statement to predict the financial distress conditions of SMEs. In addition, this study measure financial distress with only one metric, namely negative operating profit for two consecutive years.

For future study, it is recommend to use more than one proxy to assess financial distress, such as the use of interest payout ratios, negative book value of equity, negative cash flow, etc. The financial ratios used should be measured using financial ratios extracted from balance sheets, benefit and loss and cash flows and not from non-financial data with a longer observation period of time. With the right financial distress assessment mechanism, backed by reliable financial evidence, the findings of this study would be very useful for SMEs to take the requisite corrective steps to prevent bankruptcies.

\section{ACKNOWLEDGMENT}

In arranging this research, a lot of people have provided motivation, advice, and support for the researcher. In this valuable chance, the researcher intended to express her gratitude and appreciation to all of them. First, the researcher's deepest appreciation goes to State Polytechnic of Malang who has helped her finishing this research by giving guidance, motivation and fund until the completion of thsi research. The researcher greatest appreciation also goes to contributor of the data (Malang Chamber of Commerce and Industry) for his valuable insight, supervision, and crucial contribution in the improvement of the result of this research. Finally, I would like to thank everybody who was important to the successful realization of this research. This paper is far from perfect, but it is expected that it will be useful not only for the researcher, but also for the readers. For this reason, constructive thoughtfull suggestion and critics are welcomed

\section{REFERENCES}

[1] V. Chandler, "The economic impact of the Canada small business financing program”. Small Business Economics, 39(1), 253-264. 2021.

[2] D. Neumark, B. Wall, and J. Zhang, "Do Small Businesses Create More Jobs? New Evidence for The United States from the National Establishment Time Series". The Review of Economics and Statistics, 93(1), 16-29. 2011.

[3] G.D. Wit and J.D. Kok, "Do small businesses create more jobs? New evidence for Europe". Small Business Economics, 42(2), 283-295. 2014.

[4] T. Beck, A. Demirgüç-Kunt, and V. Maksimovic, "Financial and Legal Constraints to Growth: Does Firm Size Matter?" The Journal of Finance, 60(1), 137-177. 2005.

[5] P.V. Hemert, P. Nijkamp, and E. Masurel, "From innovation to commercialization through networks and agglomerations: Analysis of sources of innovation, innovation capabilities and performance of Dutch SMEs". The Annals of Regional Science, 50(2), 425-452. 2013.

[6] S. Lee, G. Park, B. Yoon, and J. Park, Open innovation in SMEs - An intermediated network model. 2010.

[7] N. Yoshino and F. Taghizadeh-Hesary, The Role of SMEs in Asia and Their Difficulties in Accessing Finance. ADBI Working Paper 911. Tokyo: Asian Development Bank Institute. Available: https://www.adb.org/publications/role-smes-asia-and-their- difficultiesaccessing-finance 2018.

[8] H.D. Pham, "Determinants of New Small and Medium Enterprises (SMEs) Access to Bank Credit: Case Study in the Phu Tho Province, Vietnam", International Journal of Business and Management; Vol. 12, No. 7. 2017.

[9] N. Geleta and S. Talegeta, "Determinants of Micro and Small Enterprises Growth in Selected Towns of West Shoa Zone, Oromia Regional State, Ethiopia”, International Journal of Small and Medium Enterprises; Vol. 2, No. 2. 2019.

[10] A.M. Taiwo, A. Ayodeji, and B. Yusuf, "Impact of Small and Medium Enterprises on Economic Growth and Development", American Journal of Business and Management Vol. 1, No. 1, p.18-22. 2012.

[11] Asian Development Bank (ADB), Asia SME Finance Monitor 2014. Manila. 2015.

[12] H.D. Platt and M.B. Platt, "Understanding differences between financial distress and bankruptcy". Review of Applied Economics, 2(1076-201687135), pp.141-157. 2006.

[13] L.S. Almilia, Kristijadi, “Analisis Rasio Keuangan Untuk Memprediksi Kondisi Financial Distress Perusahaan Manufaktur yang Terdaftar di Bursa Efek Jakarta”. JAAI, Vol. 7, No.2. 2003.

[14] L.S. Almilia, "Analisis Faktor-Faktor yang Mempengaruhi Kondisi Financial Distress Suatu Perusahaan yang Terdaftar di BEJ”, JRAI, Vol. 7, No.1. 2004

[15] E.I. Altman, E. Hotchkiss, Corporate Financial Distress and Bankruptcy. Third Edition. New York : Chesnut Hill. 2008.

[16] M.M. Hanafi, A. Halim, Analisis Laporan Keuangan. Edisi 3. Yogyakarta : Sekolah Tinggi Ilmu Manajemen YPKN. 2007.

[17] W. Widarjo, D. Setyawan, "Pengaruh Rasio Keuangan Terhadap Kondisi Financial Distress Perusahaan Otomotif'. Jurnal Bisnis dan Akuntansi, Vol. 11, No. 2, Hlm 107-119. 2009.

[18] H.S.R. Putra, Manajemen Keuangan dan Akuntansi Untuk Eksekutif Perusahaan. Jakarta : Salemba Empat. 2009.

[19] A.J. Keown, et.al., Manajemen Keuangan : Prinsip dan Penerapan. Edisi Kesepuluh. Jakarta : PT Indeks. 2010.

[20] S. Atmini, Manfaat Laba dan Arus Kas Untuk Memprediksi Kondisi Financial Distress pada Perusahaan Textille Mill Products dan Apparel 
and Other Textile Products yang Terdaftar di Bursa Efek Jakarta. SNA VIII Solo. 2005.

[21] Kasmir, Analisis Laporan Keuangan. Jakarta: PT Raja Grafindo Persada. 2008.

[22] L. Syamsuddin, Manajemen Keuangan Perusahaan. Jakarta: PT Raja Grafindo. 2004.

[23] K.R. Subramanyam and J.W. John, Analisis Laporan Keuangan, Buku Satu, Edisi Sepuluh, Salemba Empat, Jakarta. 2010.
[24] P.R.B. Fernando, "Penggunaan Binary Logit Untuk Prediksi Financial Distress Emiten di BEI". Jurnal Ekonomi Bisnis \& Akuntansi Ventura, Vol. 11. No. 2. 2008.

[25] L.S. Almilia, "Prediksi Kondisi Financial Distress Perusahaan Go Public dengan Menggunakan Analisis Multinomial Logit". Jurnal Ekonomi dan Bisnis, Vol. XII, No.1. 2006.

[26] M. Salehi, "Financial Distress Prediction in Emerging Market: Empirical Evidence From Iran”. Business Inteligence Journal, Vol. 2. No. 2. 2009. 